\title{
Rates of Agricultural Gypsum in Soil Under No-tillage System With Surface Lime in the Southern of Brazil
}

\author{
Elaine Damiani Conte ${ }^{1}$, Leonardo Oliboni do Amaral $^{2}$, Charle Kramer Borges de Macedo ${ }^{2}$, Taísa Dal Magro ${ }^{1}$, \\ Lucas de Ross Marchioretto $^{2}$, Vilson Osmar Schenkel ${ }^{1} \&$ Elias da Silva Scopel $^{1}$ \\ ${ }^{1}$ Campus Universitário de Vacaria, Universidade de Caxias do Sul, Vacaria, Brazil \\ ${ }^{2}$ Centro de Ciências Agroveterinárias, Universidade do Estado de Santa Catarina, Lages, Brazil \\ Correspondence: Elaine Damiani Conte, Campus Universitário de Vacaria, Universidade de Caxias do Sul, \\ Vacaria, Brazil. Tel: 55-549-694-9414. E-mail: edconte@ucs.br
}

Received: August 6, 2018

doi:10.5539/jas.v10n11p544

\author{
Accepted: September 6, $2018 \quad$ Online Published: October 15, 2018 \\ URL: https://doi.org/10.5539/jas.v10n11p544
}

\begin{abstract}
At the no-tillage system, the surface liming is a good environmental practice, which aims to maintain the physical structure and stocks of carbon in the soil. However, the acidity amelioration is restricted to the surface layer and the use of the gypsum can be an alternative to improve the chemical conditions in subsurface without the soil revolving. The purpose of this experiment was to evaluate the effect of different rates of gypsum, estimated by different methods, in acid soils with application of superficial limestone since the beginning of the implementation of the no-tillage system. The experiment was conduct at a commercial cropping field located at the municipally of Muitos Capões, RS, Southern Brazil in a Red Oxisol. The experiment was conducted in randomized completely blocks design (RCBD), with six treatments and four replications. The treatments consisted of the superficial application of gypsum in the rates: $0,3100,6014,7875,9750$ and $12400 \mathrm{~kg} \mathrm{ha}^{-1}$. At this area, soybean and corn were cultivated and have their productivity evaluated. After 4 and 16 months of the experiment, $\mathrm{Ca}, \mathrm{Mg}$ and $\mathrm{K}$ levels were evaluated at different depths $(0-5,5-10,10-20,20-30$ and $30-40 \mathrm{~cm})$. The results showed an increase in Ca contents to the depth of $10 \mathrm{~cm}$ at 4 months after application and at all depths evaluated at 16 months after their application. The application of gypsum decreases the Mg contents to the depth of $20 \mathrm{~cm}$ and of potassium at all the depths after 16 months of their application. The effects on soil chemical properties with increasing rate of applied gypsum resulted in higher maize grain yield. So, agricultural gypsum applied in the soil with surface liming is efficient in improving soil chemical conditions in deeper layers in a no-tillage system.
\end{abstract}

Keywords: acidity amelioration, Glycine max, Zea mays

\section{Introduction}

No-tillage system has emerged as an efficient alternative to ensure sustainability in tropical and subtropical soils, especially in Brazil. In most of these soils the acidity has been limiting for the development of the grain crops, being used the practice of surface liming and/or incorporated. Yagi, Fidalski and Tormena (2014) found that the incorporation of limestone in soil reduced the carbon stocks of the macroaggregates in the $0-10 \mathrm{~cm}$ layer and concluded that surface liming is fundamental for the maintenance and increase of these stocks. However, the action of lime without incorporation can be restricted to the surface layer of acid soils (Miyazawa, Pavan \& Franchini, 2002) and limiting the deepening of roots.

Agricultural gypsum, a byproduct of phosphate fertilizer manufacture, in surface applications is an alternative for improvements in soil chemical characteristics in depth, avoiding soil mobilization in no-tillage system areas and increasing plant tolerance to periods of water deficit. Its effect is known to carry basic cations in subsurface, reduce aluminum saturation (Ritchey, Sousa, Lobato, \& Correa, 1980) and aluminum toxicity (Sumner, 1995). However, these potential changes do not necessarily translate into increases in crop yields (Zoca \& Penn, 2017). Improvement in crop yield may be the result of an additive or synergistic effect of each of these potential changes, and they vary with crop, soil type and rainfall regime (Zoca \& Penn, 2017).

The available knowledge about the effect of gypsum in subtropical soils of Southern Brazil, about the crop yield is incipient mainly for soils under no-tillage system (Tiecher, Pias, Bayer, Martins, Denardin, \& Anghinoni, 
2018). Therefore, there are many doubts about the most appropriate methods to estimate their need (Guimaraes, Caires, Silva, \& Rocha, 2015) and there are no official recommendations on gypsum for the states of Rio Grande do Sul and Santa Catarina (CQFS-RS/SC, 2016), although it is a common practice among farmers. Mistaken rates can lead to large leaching of nutrients and, consequently, loss to subsurface layers such as Magnesium (Caires, Kusman, Barth, Garbuio, \& Adilha, 2004).

For Souza, Lobato and Rein (2005) if saturation by aluminium (Al) is higher than $20 \%$ or calcium $(\mathrm{Ca})$ content is lower than $0.5 \mathrm{cmol}_{\mathrm{c}} \mathrm{dm}^{-3}$, there is a probability of a response to gypsum, and under these conditions the amount of gypsum to be applied according to these authors is based on the clay content of the soil. Malavolta (1992) recommends the use of agricultural gypsum whenever there is less than $40 \%$ of $\mathrm{Ca}$ in the effective cation exchange capacity or when the saturation in $\mathrm{Al}$ is greater than $20 \%$; Under these conditions, the rate of gypsum is based on the assumption that $2.5 \mathrm{tha}^{-1}$ of gypsum is required to raise or lower $1 \mathrm{cmol}_{\mathrm{c}} \mathrm{dm}^{-3}$ of Ca and/or Al. According to Guimaraes, Caires, Silva and Rocha (2015) the saturation by $\mathrm{Ca}$ in the effective cations exchange capacity was a more important attribute than the saturation by Al to estimate the need for gypsum in soils under no-tillage. Recently, Tiecher, Pias, Bayer, Martins, Denardin \& Anghinoni (2018) analyzing the results of 73 experiments, reported in 20 scientific publications, concluded that for grasses cultivated in subtropical latosols under no-tillage system, the use of $10 \% \mathrm{Al}$ and/or $3.0 \mathrm{cmol}_{\mathrm{c}} \mathrm{dm}^{-3}$ of exchangeable $\mathrm{Ca}$ in the subsurface soil layer $(0.20-0.40 \mathrm{~m})$ is more suitable than the current recommendation (Al saturation of $20 \%$ and $/$ or $0.5 \mathrm{cmol}_{\mathrm{c}} \mathrm{dm}^{-3} \mathrm{Ca}$ ) for tropical soils. Soils with superficial application of limestone, since the implantation of the crops under no-tillage system, can present these limitations even in the layer of $10-20 \mathrm{~cm}$ of depth. In these cases, the incorporation of limestone is considered (CQFS-RS/SC, 2016).

Therefore, it is necessary to evaluate efficient rates for surface application in soils with high potential acidity and high levels of organic matter, searching for alternative strategies of soil correction in depth without its mobilization and that can reach the deeper layers of soil. The objective of this study was to evaluate the effect of different rates of gypsum, estimated by different methods in acid soils with surface liming application from the beginning of the no-tillage system.

\section{Materials and Methods}

The experiment was carried out in the municipality of Muitos Capões-RS-Southern Brazil $\left(28^{\circ} 20^{\prime} \mathrm{S} 51^{\circ} 7^{\prime} \mathrm{W}\right)$ in Red Oxisol, for two consecutive harvests, in no-tillage areas established under native land without any soil disturbance.

The soil where it was conducted had the following chemical characteristics, before to the implantation of the experiment, at 0-10 cm depth: $\mathrm{pH} 4.8$, SMP index 5.1, organic matter (OM) $6.2 \%$, calcium (Ca) $6.0 \mathrm{cmol}_{\mathrm{c}} \mathrm{dm}^{-3}$; magnesium (Mg) $2.4 \mathrm{cmol}_{\mathrm{c}} \mathrm{dm}^{-3}$, aluminum (Al) $1.3 \mathrm{cmol}_{\mathrm{c}} \mathrm{dm}^{-3} ; \mathrm{H}+\mathrm{Al} 12.3 \mathrm{cmol}_{\mathrm{c}} \mathrm{dm}^{-3}$; effective cation exchange capacity (ECEC) $10.4 \mathrm{cmol}_{\mathrm{c}} \mathrm{dm}^{-3}$, cation exchange capacity at pH7.0 (CEC) $21.4 \mathrm{cmol}_{\mathrm{c}} \mathrm{dm}^{-3}$, bases saturation (V) 43\%; phosphorus (P) $12.8 \mathrm{mg} \mathrm{dm}^{-3}$, sulfur (S) $17.5 \mathrm{mg} \mathrm{dm}^{-3}$ and potassium (K) $284 \mathrm{mg} \mathrm{dm}^{-3}$.

For use as a gypsum recommendation criterion, the $10-20 \mathrm{~cm}$ layer was sampled, with the following chemical characteristics: $\mathrm{pH} 4.4$, SMP 4.7, MO 4.5\%, Ca $2.0 \mathrm{cmol}_{\mathrm{c}} \mathrm{dm}^{-3} ; \mathrm{Mg} 1.2 \mathrm{cmol}_{\mathrm{c}} \mathrm{dm}^{-3} ; \mathrm{Al} 3.9 \mathrm{cmol}_{\mathrm{c}} \mathrm{dm}^{-3} ; \mathrm{H}+\mathrm{Al}$ $19.4 \mathrm{cmol}_{\mathrm{c}} \mathrm{dm}^{-3}$; ECEC $7.5 \mathrm{cmol}_{\mathrm{c}} \mathrm{dm}^{-3}$, CEC $23 \mathrm{cmol}_{\mathrm{c}} \mathrm{dm}^{-3}$, V 16\%; P $2.5 \mathrm{mg} \mathrm{dm}^{-3}$, S $21 \mathrm{mg} \mathrm{dm}^{-3}$ and K $148 \mathrm{mg}$ $\mathrm{dm}^{-3}$.

Before the installation of the experiment the superficial application of acidic corrector, Macro-calcium $\mathrm{ES}^{\circledR}$, relative power of total neutralization ( $\mathrm{PRNT}) 75.6 \%(\mathrm{CaO}=51 \%$ to $53 \% \mathrm{MgO}=0.2 \%)$ in the medium rate to reach saturation of bases of $80 \%$

The experiment was conducted in randomized completely blocks design (RCBD), with six treatments and four replications. The treatments consisted of different rates of gypsum applied manually at the soil surface (Table 1). The rates of gypsum used were adapted from Souza, Lobato, and Rein (2005), and Malavolta (1992). The recommendations of the agricultural gypsum rates were calculated based on the soil layer of 10-20 cm depth. 
Table 1. Description of treatments used without experiment, Vacaria-RS, Southern Brazil, 2018

\begin{tabular}{|c|c|c|c|}
\hline Treatment & Recommendation & Gypsum Rate & Calculation \\
\hline 1 (untreated) & Without application of agricultural plaster & - & - \\
\hline 2 & Souza, Lobato, and Rein (2005) & $3.100 \mathrm{Kg} \mathrm{ha}^{-1}$ & G.R. $\left(\mathrm{Kg} \mathrm{ha}^{-1}\right)=50 \times$ clay $(\%)$ \\
\hline \multirow{2}{*}{3} & Adapted by Souza, Lobato and Rein (2005) & \multirow{2}{*}{$6.014 \mathrm{Kg} \mathrm{ha}^{-1}$} & G.R. $\left(\mathrm{Kg} \mathrm{h}^{-1}\right)=97 \times$ clay $(\%)$ \\
\hline & Malavolta (1992) & & $\mathrm{N} . \mathrm{G}=\left(\right.$ meq Al $\left.100 \mathrm{~cm}^{-3}-0.2 \mathrm{ECEC}\right) \times 2.5$ \\
\hline 4 & Adapted by Malavolta (1992) & $7.875 \mathrm{Kg} \mathrm{ha}^{-1}$ & $\mathrm{~N} . \mathrm{G}=\left(\mathrm{meq} \mathrm{Al} 100 \mathrm{~cm}^{-3}-0.1 \mathrm{ECEC}\right) \times 2.5$ \\
\hline 5 & Adapted by Malavolta (1992) & $9.750 \mathrm{Kg} \mathrm{ha}^{-1}$ & $\mathrm{~N} . \mathrm{G}=\left(\right.$ meq Al $100 \mathrm{~cm}^{-3}-0$ ECEC $) \times 2.5$ \\
\hline 6 & Adapted by Souza, Lobato, and Rein (2005) & $12.400 \mathrm{Kg} \mathrm{ha}^{-1}$ & G.R. $\left(\mathrm{Kg} \mathrm{ha}^{-1}\right)=200 \times \operatorname{clay}(\%)$ \\
\hline
\end{tabular}

Note. G.R. $=$ Gypsum rate; N.G.: Need of Gypsum; ECEC: Effective Cation Exchange Capacity.

The gypsum applied rate treatment followed the recommendation of treatment 2: Souza, Lobato, and Rein (2005), which recommends annual crops to $50 \mathrm{Kg} \mathrm{ha}^{-1}$ of gypsum by the clay content. In treatments 3 and 6 (Table 1) an adaptation was carried out, using 97 and $200 \mathrm{Kg} \mathrm{ha}^{-1}$ respectively per clay content, both treatments mentioned above did not consider the subsurface layer of 20 to $40 \mathrm{~cm}$ as recommended by the author, but the layer of 10 a $20 \mathrm{~cm}$ deep. Since chemical conditions at depths of 10 to $20 \mathrm{~cm}$ are not ideal for root development and should be ameliorated.

Treatments 4 and 5 (Table 1) were adaptation of the Malavolta (1992) recommendation, respectively using $(0.1)$ and $(0.0)$, considering reduce $\mathrm{Al}$ saturation of $10 \%(0.1)$ and $0 \%(0)$. The agricultural gypsum used was with $17.22 \%$ of moisture and solubility $2.63 \mathrm{~g} \mathrm{~L}^{-1}$.

In the experimental area, the soybean cultivar BMX Titan 5.3i $\mathrm{RR}^{\circledR}$, was implanted. The spacing between lines was $0.45 \mathrm{~m}$. The fertilization was carried out in the sowing line, and $80 \mathrm{Kg} \mathrm{ha}^{-1}$ of diammonium phosphate (DAP) was applied. Potassium chloride was applied in the furrow to achieve base saturation of $0.4 \%$. The following year the corn crop, AS1555g hybrid, was implanted. The fertilization used was $300 \mathrm{Kg} \mathrm{ha}^{-1}$ of Urea Plus ${ }^{\circledR}$.

After the cultivation, the cultures were harvested manually. In order to evaluate the yield components of each crop (soybean and corn), it was considered a useful area per plot consisting of five central rows, $5.0 \mathrm{~m}$ long, totalizing $11.25 \mathrm{~m}^{2}$, always discarding the ends of the plots in the lengthwise direction $(3 \mathrm{~m}$ on one side and $2 \mathrm{~m}$ on the other side) and discarding the external rows (6 rows) of the plot. Productivity calculation was corrected to $13 \%$ moisture.

Soil chemical evaluations were performed at 4 and 16 months after the application of gypsum to the depths of $0-5,5-10,10-20,20-30$ and $30-40 \mathrm{~cm}$. The sub-samples were collected using the two center rows of each useful plot, there was obtained two subsamples per plot to form a sample. They were collected with two cutting blades with a blade of $45 \mathrm{~cm}$ depth, and a soil profile was drawn in a line perpendicular to the direction of the rows, with a width of $14 \mathrm{~cm}$ and a thickness of approximately $4 \mathrm{~cm}$. In these samples the $\mathrm{Ca}, \mathrm{Mg}$ and $\mathrm{K}$ contents were determined (Tedesco, Gianello, Bissani, Bohnen, \& Wolkweiss, 1995).

During the crop cycle, rainfall monitoring was carried out through the use of an analogue rain gauge installed in the crop.

The results of the evaluations were submitted to analysis of variance $(\mathrm{p} \leq 0.05)$; and, in case of significance, rate effects were compared by analysis of regression. The magnitude of the significant coefficients of determination at $5 \%$ of probability was adopted as the criterion for choosing the model.

\section{Results and Discussion}

\subsection{Soil Chemical Parameters}

The application of agricultural gypsum significantly influenced the Ca contents in the soil in the two evaluations, and only 4 months after the application there was interaction with the soil depth (Figure 1). These results demonstrate that the effect of the application occurs gradually over time, and at 16 months the effect of the application was linear and reached all depths evaluated $(0-40 \mathrm{~cm})$. 

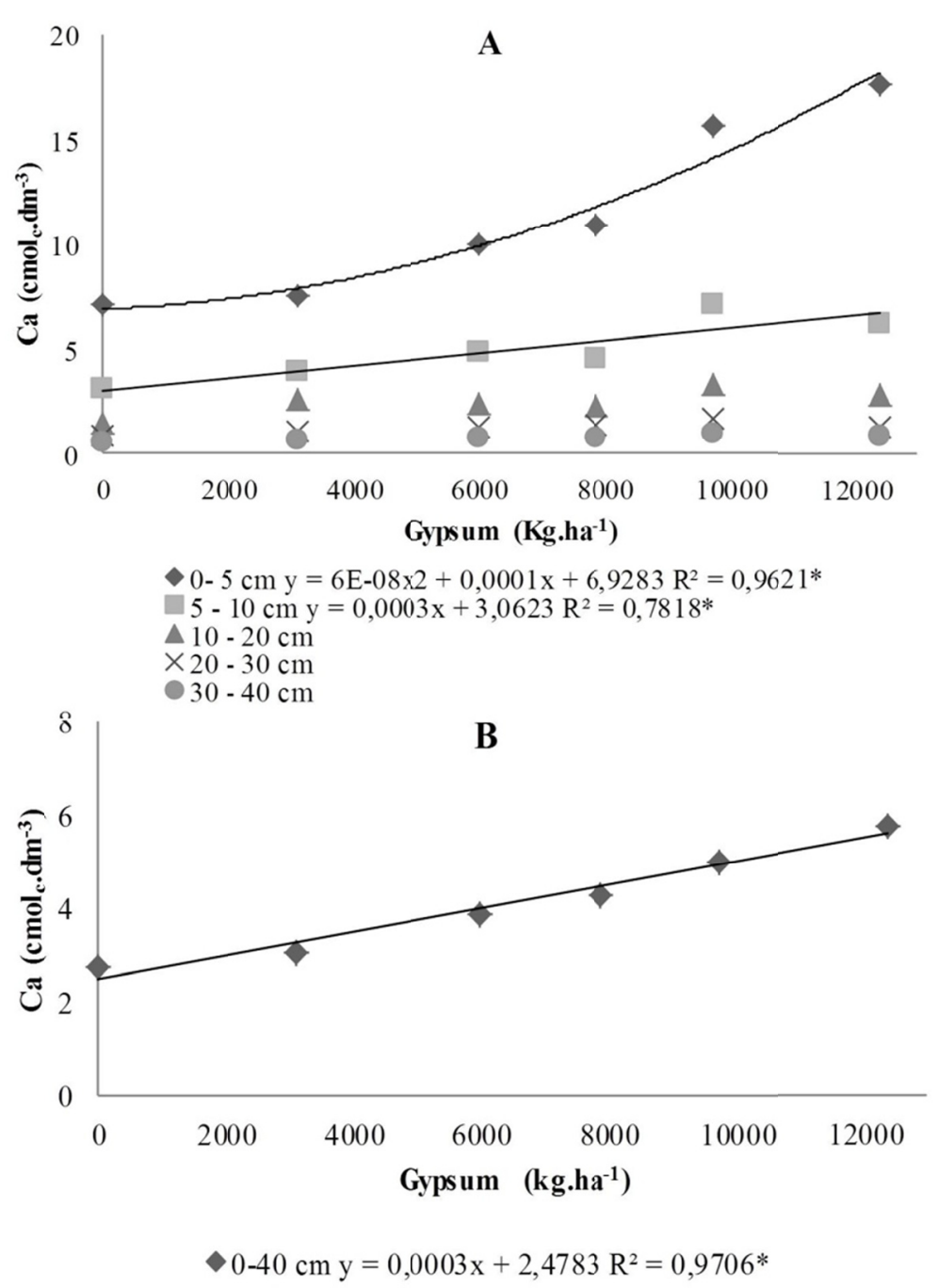

Figure 1. Ca contents in soil with superficial application of different levels of gypsum in a consolidated no-tillage system after 4 months (A) at different depths and after 16 months (B) average depth 0-40 $\mathrm{cm}$. Vacaria-RS,

Southern Brazil, 2018

Note. * significant $\mathrm{P}<0.05$.

Similar to this experiment, Pauletti, Pierri, Ranzan Barth, and Motta (2014) observed increased Ca at all depths evaluated in proportion to the applied gypsum rates $\left(0,1.5,3.0,6.0\right.$, and 12.0 ton $\left.\mathrm{ha}^{-1}\right)$, and the longer the period between the application and analysis of the soil was more pronounced the effect.

The Mg contents presented interaction with the depths evaluated in the two evaluation periods (Figure 2). At 4 months after the evaluation, the application of gypsum reduced the contents of $\mathrm{Mg}$ up to $20 \mathrm{~cm}$ depth, indicating a leaching of this nutrient in the profile. The leaching of $\mathrm{Mg}$ was confirmed in the evaluation at 16 months, where there was a reduction in its soil contents up to the $20 \mathrm{~cm}$ layer and a significant linear increase in the layer of 30 to $40 \mathrm{~cm}$, not detected at 4 months, probably the lowest leaching and the natural variability of the soil. 


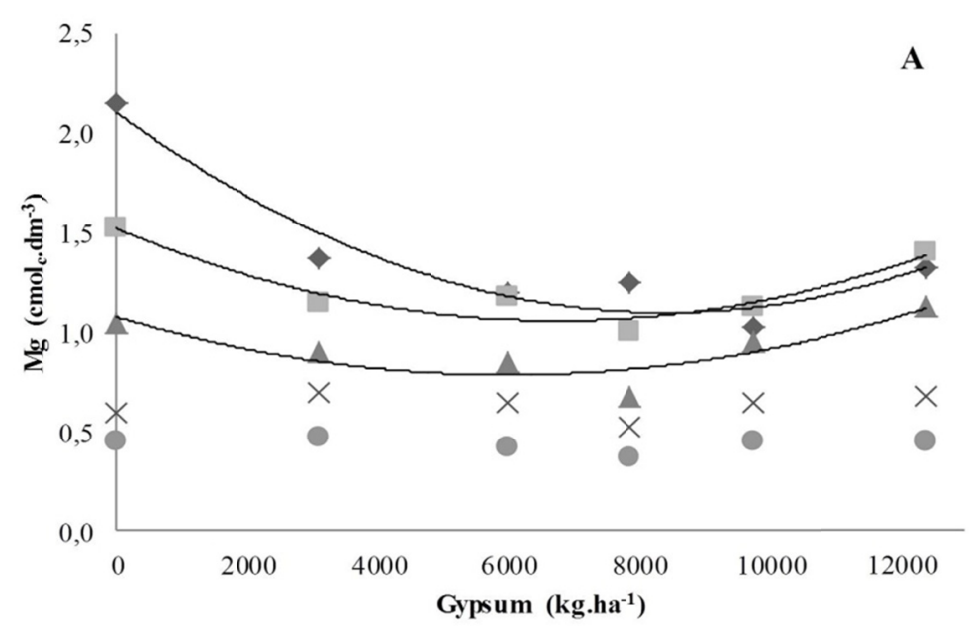

४ $0-5 \mathrm{~cm} \mathrm{y}=1 \mathrm{E}-08 \mathrm{x} 2-0,0002 \mathrm{x}+2,1014 \mathrm{R}^{2}=0,9358 *$

$5-10 \mathrm{~cm} y=1 \mathrm{E}-08 \times 2-0,0001 \mathrm{x}+1,5205 \mathrm{R}^{2}=0,893 *$

$\Delta 10-20 \mathrm{~cm} \mathrm{y}=8 \mathrm{E}-09 \times 2-1 \mathrm{E}-04 \mathrm{x}+1,0758 \mathrm{R}^{2}=0,7682 *$

$\times 20-30 \mathrm{~cm}$

$30-40 \mathrm{~cm}$

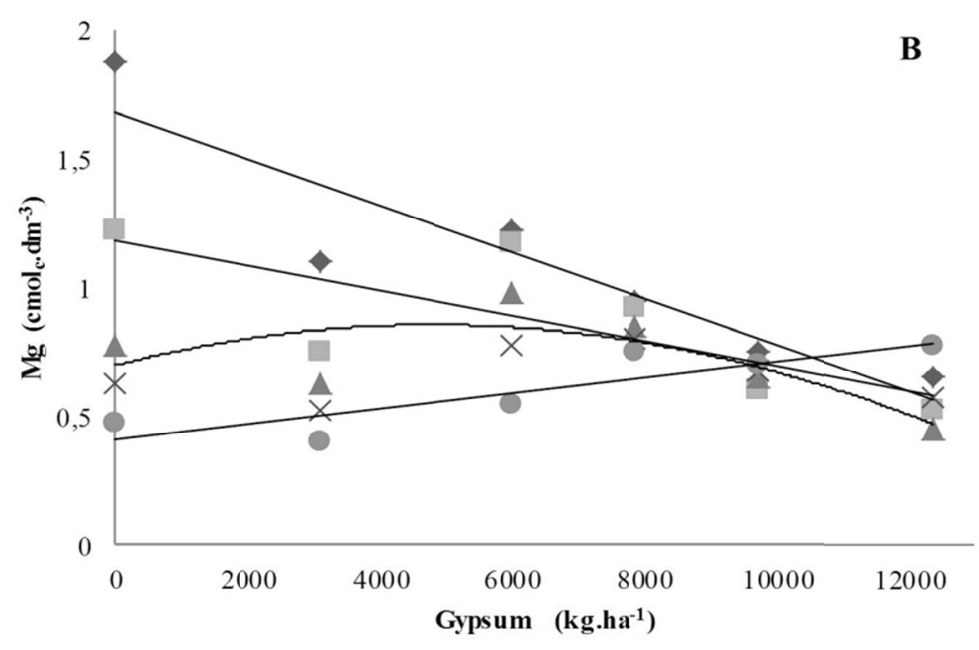

$$
\begin{aligned}
& \text { - } 0 \text { - } 5 \mathrm{~cm} \mathrm{y}=-9 \mathrm{E}-05 \mathrm{x}+1,6774 \mathrm{R}^{2}=0,8478 * \\
& 5-10 \mathrm{~cm} \mathrm{y}=-5 \mathrm{E}-05 \mathrm{x}+1,1812 \mathrm{R}^{2}=0,5499 * \\
& \Delta 10-20 \mathrm{~cm} \mathrm{y}=-7 \mathrm{E}-09 \mathrm{x} 2+7 \mathrm{E}-05 \mathrm{x}+0,6976 \mathrm{R}^{2}=0,58^{*} \\
& \times 20-30 \mathrm{~cm} \\
& 30-40 \mathrm{~cm} \mathrm{y}=3 \mathrm{E}-05 \mathrm{x}+0,41 \mathrm{R}^{2}=0,7747 *
\end{aligned}
$$

Figure 2. Mg contents in soil with superficial application of different rates of gypsum in a consolidated no-tillage system after 4 months (A) and 16 months (B) at different depths. Vacaria-RS, Southern Brazil, 2018

Note. * significant $\mathrm{P}<0.05$.

The Mg leaching by the application of gypsum was also observed by other authors (Pavan \& Roth, 1992; Caires, Chueiri, Madruga, \& Figueiredo, 1998; Caires, Kusman, Barth, Garbuio, \& Adilha, 2004; Blum, Caires, Ayub, Fonseca, Sozim, \& Fauate, 2011; Rampim, Lana, Frandoloso, \& Fontaniva, 2011; Nava, Ernani, Sa, \& Pereira, 2012; Pauletti, Pierri, Ranzan, Barth, \& Motta, 2014; Crusciol, Foltran, Rossato, McCray, \& Rossetto, 2014; Vicensi, Müller, Kawakami, Nascimento, Michalovicz, \& Lopes, 2016). The mobility of Mg can be explained in part by the formation of neutral ionic pairs with sulfate $\left(\mathrm{SO}_{4}^{-}\right)$(Zambrosi, Alleoni, \& Caires, 2007).

Although this work showed an increase in $\mathrm{Mg}$ contents in layer 30 to $40 \mathrm{~cm}$, in the lower depths the values were reduced with the increase of the rate of gypsum applied. Considering adequate values of $\mathrm{Mg}$ above $1.0 \mathrm{cmol}_{\mathrm{c}}$ $\mathrm{dm}^{-3}$ (CQFSRS/SC, 2016), there was a reduction below this level at depth of $0-10 \mathrm{~cm}$ from the rate of $7875 \mathrm{Kg}$ 
$\mathrm{ha}^{-1}$ of applied gypsum. Therefore, at high rates this reduction may be the limiting factor for the development of the plants and strategies should be developed to minimize losses of $\mathrm{Mg}$.

The $\mathrm{K}$ contents presented similar effect in all depths, without interaction of plaster rate and soil depth (Figure 3). Only in the evaluation at 16 months a significant adjustment to the data was observed, with a reduction in the $\mathrm{K}$ contents of the soil in a linear manner as the rate of gypsum applied increased, regardless of the depth evaluated. The average values of $\mathrm{K}$ at the depth of $0-10 \mathrm{~cm}$ were 0.460 and $0.328 \mathrm{cmol}_{\mathrm{c}} \mathrm{dm}^{-3}$ respectively, at 4 and 16 months after application of gypsum. These values are considered high for the evaluated crops, in this type of soil (CQFSRS/SC, 2016).

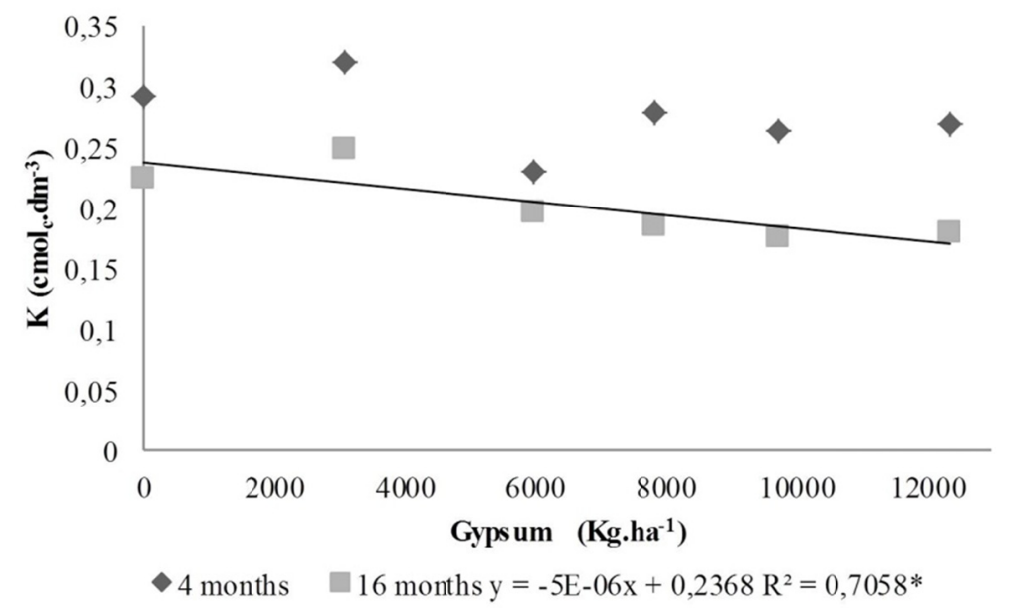

Figure 3. K levels in the soil after 4 months and 16 months of superficial application of different rates of gypsum in a consolidated no-tillage system, depth average of 0-40 cm. Vacaria-RS, Southern Brazil, 2018

Note. * significant $\mathrm{P}<0.05$.

The losses of $\mathrm{K}$ in the soil due to the application of agricultural gypsum in a no-tillage system are not a consensus among the experiments in the soils of Brazil. Several studies have found small or no losses of this nutrient (Caires, Chueiri, Madruga, \& Figueiredo, 1998; Caires, Kusman, Barth, Garbuio, \& Adilha, 2004). It should be noted that in this experiment the soil collection was carried out during the maturation period of the plant and therefore, some of the nutrients were still in the plant in different amounts according to their plant height and productivity. On the other hand, Crusciol, Foltran, Rossato, McCray, and Rossetto (2014) observed that the application of gypsum promoted reduction in the content of $\mathrm{K}$ up to the depth of $0.40 \mathrm{~m}$ and increase in the layer of $0.40-0.60 \mathrm{~m}$ and attributed to leaching of the nutrient in the profile. So, it is suggested that the long-term potassium levels be monitored in greater depth in this type of soil.

\subsection{Production Cultures}

The yield of the soybean crop, the first crop after the application of the limestone, did not present significant effect due to the application of agricultural gypsum in the soil, presenting a mean of $4.112 \mathrm{Kg} \mathrm{ha}^{-1}$ (coefficient of variation $6.43 \%$ ). In the next crop, corn was observed a linear increase in plant height (Figure 4 ) and a quadratic increase in crop yield (Figure 5). 


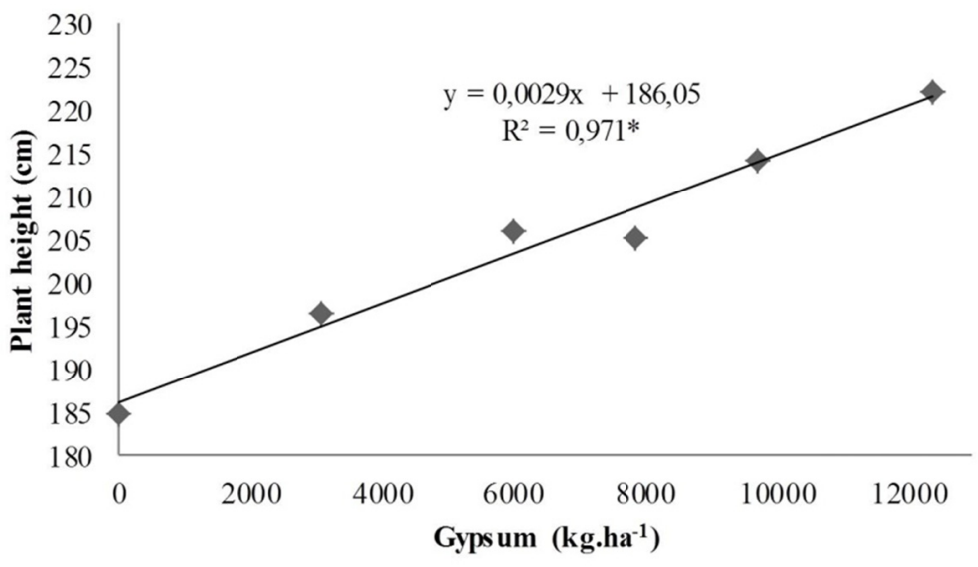

Figure 4. Height of corn plants in face of the use of different rates of gypsum in a consolidated no-tillage system. Vacaria-RS, Southern Brazil, 2018

Note. * significant $\mathrm{P}<0.05$.

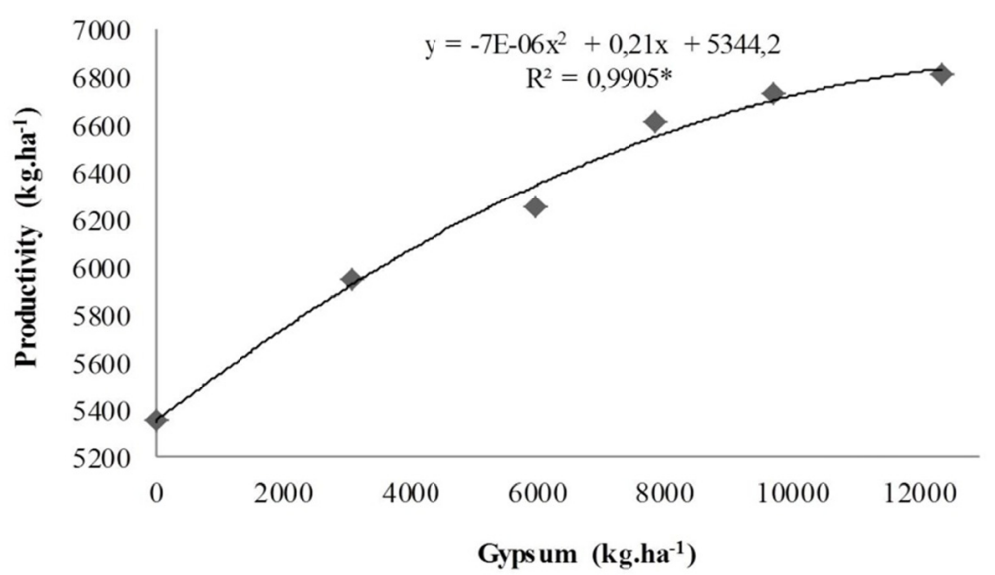

Figure 5. Corn productivity in relation to the use of different rates of gypsum in a consolidated no-tillage system. Vacaria-RS, Southern Brazil, 2018

Note. * significant $\mathrm{P}<0.05$.

These results reflect the chemical effects on soil that intensified at 16 months after the superficial application of gypsum. It should be noted also that during the soybean cycle (1 Cultivation) precipitation was regular with an average of $204 \mathrm{~mm}$ while the next month culture was uneven precipitation and monthly average of $98 \mathrm{~mm}$. According to Pauletti, Pierri, Ranzan, Barth, and Motta (2014) the application of gypsum increases grass productivity and influences legumes mainly in years with water deficiency. According to Tiecher, Pias, Bayer, Martins, Denardin, and Anghinoni (2018) legumes, such as soybeans, are more efficient in absorbing Ca from the soil solution than grasses and therefore are less likely to provoke a positive response to the application of gypsum in soybean.

The yield gain at each gypsum rate increase evaluated in this experiment were $598 \mathrm{~kg} \mathrm{ha}^{-1}$ (T2-T1), $305 \mathrm{~kg} \mathrm{ha}^{-1}$ (T3-T2), $365 \mathrm{~kg} \mathrm{ha}^{-1}$ (T4-T3), $114 \mathrm{~kg} \mathrm{ha}^{-1}$ (T5-T4) and $83 \mathrm{~kg} \mathrm{ha}^{-1}$ (T6-T5) (Table 1). It should be noted that crop responses to improvements in subsurface chemical conditions are variable with the species used and associated with periods of water deficiency (Caires, Feldhaus, \& Blum, 2001; Broch, Nolla, Quiqui, \& Possenti, 2008; Soratto \& Crusciol, 2008, Pauletti, Pierri, Ranzan, Barth, \& Motta, 2014; Tiecher, Pias, Bayer, Martins, Denardin, \& Anghinoni, 2018).

Recently, Caires and Guimarães (2016) proposed a new method of gypsum recommendation for soils in southern Brazil. The method is based on calculating the need for gypsum $\left(\mathrm{NG}\right.$, in $\left.\mathrm{tha}^{-1}\right)$ to increase the saturation by Ca in the $\mathrm{CEC}$ and the $60 \%$ subsoil $(20-40 \mathrm{~cm})$ when it is less than $50 \%$, by means of equation: $\mathrm{NG}=(0.6 \times \mathrm{eCEC}-$ 
Ca content in $\left.\mathrm{cmol}_{\mathrm{c}} \mathrm{dm}^{-3}\right) \times 6.4$. Using this equation, but with the decision criterion the $0-10 \mathrm{~cm}$ layer, the required rate of gypsum in this soil would be 16 ton $\mathrm{ha}^{-1}$, higher than the rate tested in this work. So, suggesting that higher rates to this work are tested under these conditions and especially, the losses of $\mathrm{Mg}$ and $\mathrm{K}$ in the system were evaluated.

\section{Conclusion}

The gypsum in soil with surface liming is efficient in improving soil chemical conditions in deeper layers without the need for soil mobilization in no-tillage cropping systems.

\section{References}

Blum, J., Caires, E. F., Ayub, R. A., Fonseca, A. F. D., Sozim, M., \& Fauate, M. (2011). Soil Chemical Attributes and Grape Yield as Affected by Gypsum Application in Southern Brazil.Communications in Soil Science and Plant Analysis, 42, 1434-1446. https://doi.org/10.1080/00103624.2011.577861

Broch, D. L., Nolla, A., Quiqui, E. M. D., \& Possenti, J. C. (2008). Influência no Rendimento de Plantas de Soja pela Aplicação de Fósforo, Calcário e Gesso em um Latossolo Sob Plantio Direto. Revista Ciências Exatas e Naturais, 10(2), 211-220.

Caires, E. F., Chueiri, W. A., Madruga, E. F., \& Figueiredo, A. (1998). Alterações de características químicas do solo e resposta da soja ao calcário e gesso aplicados na superfície em sistema de cultivo sem preparo do solo. Rev. Bras. Ciênc, 22(1), 27-34. https://doi.org/10.1590/S0100-06831998000100004

Caires, E. F., Feldhaus, I. C., \& Blum, J. (2001). Crescimento radicular e nutrição da cevada em função da calagem e aplicação de gesso. Bragantia, 60, 213-223. https://doi.org/10.1590/S0006-87052001000300009

Caires, E. F., Kusman, M. T., Barth, G., Garbuio, F. J., \& Adilha, J. M. (2004). Alterações químicas do solo e resposta do milho à calagem e aplicação de gesso. R. Bras. Ci. Solo, 28,125-136. https://doi.org/10.1590/ S0100-06832004000100013

Caires, E. F., Silva, K. S., \& Rocha, J. C. F. (2015). Estimating gypsum requirement under no-till based on machine learning technique. Revista Ciência Agronômica, 46, 250-257.

CQFS-RS/SC (Comissão de Química e Fertilidade do Solo-RS/SC). (2016). Manual de calagem e adubação para os Estados do Rio Grande do Sul e de Santa Catarina (11th ed., p. 376). Sociedade Brasileira de Ciência do Solo, Núcleo Regional Sul.

Crusciol, C. A. C., Foltran, R., Rossato, O. B., McCray, J. M., \& Rossetto, R. (2014). Effects of surface application of calcium-magnesium silicate and gypsum on soil fertility and sugarcane yield. Rev. Bras. Ciênc. Solo, 38(6), 1843-1854. https://doi.org/10.1590/S0100-06832014000600019

Guimarães, A. M. (2016). Recomendação de gesso para solos sob plantio direto da região Sul do Brasil. In FertBio 2016, Goiânia. Anais: FertBio 2016. Viçosa: Sociedade Brasileira de Ciência do Solo.

Malavolta, E. (1992). Gesso Agrícola no ambiente e na nutrição da planta-perguntas e respostas (p. 413). Seminário sobre uso do gesso na Agricultura. IBRAFOS, Uberaba.

Miyazawa, M., Pavan, M. A., \& Franchini, J. C. (2002). Evaluation of Plant Residues on the Mobility of Surface Applied Lime. Braz. Arch. Biol. Technol, 45(3), 251-256. https://doi.org/10.1590/S1516-891320020003 00001

Nava, G., Ernani, P. R., \& Pereira, A. J. (2012). Soil composition and nutritional status of apple as affected by long-term application of gypsum. Rev. Bras. Ciênc. Solo, 36(1), 215-222. https://doi.org/10.1590/S0100-068 32012000100022

Pauletti, V., Pierri, L. de, Ranzan, T., Barth, G., \& Motta, A. C. V. (2014). Efeitos em longo prazo da aplicação de gesso e calcário no sistema de plantio direto. Rev. Bras. Ciênc. Solo, 38(2), 495-505. https://doi.org/10.1590/ S0100-06832014000200014

Pavan, M. A., \& Roth, C. H. (1992). Effect of lime and gypsum on chemical composition of runoff and leachate from samples of a Brazilian oxisol. Ciência e Cultura (São Paulo), 44(6), 391-394.

Rampim, L., Lana, M. C., Frandoloso, J. F., \& Fontaniva, S. (2011). Atributos químicos de solo e resposta do trigo e da soja ao gesso em sistema semeadura direta. Rev. Bras. Ciênc. Solo, 35(5), 1687-1698. https://doi.org/ $10.1590 / \mathrm{S} 0100-06832011000500023$ 
Ritchey, K. D., Sousa, D. M. G., Lobato, E., \& Correa, O. (1980). Calcium leaching to increase rooting depth in a Brazilian Savannah Oxisol. Agron. J., 72, 40-44. https://doi.org/10.2134/agronj1980.000219620072000 10009x

Soratto, R. P., \& Crusciol, C. A. C. (2008). Atributos químicos do solo decorrentes da aplicação em superfície de calcário e gesso em sistema plantio direto recém-implantado. Rev. Bras. Ciênc. Solo, 32(2), 675-688. https://doi.org/10.1590/S0100-06832008000200026

Souza, D. M. G., Lobato, E., \& Rein, T. A. (2005). Uso gesso de agrícola em solos do cerrado. Circular Técnica, Planaltina, 32, 19.

Sumner, M. E. (1995). Amelioration of subsoil acidity with minimum disturbance. In N. S. Jayawardane, \& B. A. Stewart (Eds.), Subsoil management techniques (pp. 147-185). Athens, GA, Lewis Publishers.

Tiecher, T., Pias, O. H. C., Bayer, C., Martins, A. P., Denardin, L. G. O., \& Anghinoni, I. (2018). Crop Response to Gypsum Application to Subtropical Soils Under No-Till in Brazil: A Systematic Review. Rev. Bras. Ciênc. Solo, 42, e0170025. https://doi.org/10.1590/18069657rbcs20170025

Vicensi, M., Müller, M. M. L., Kawakami, J., Nascimento, R., Michalovicz, L., \& Lopes, C. (2016). Do Rates and Splitting of Phosphogypsum Applications Influence the Soil and Annual Crops in a No-Tillage System? Rev. Bras. Ciênc. Solo, 40, 0150-155. https://doi.org/10.1590/18069657rbes20150155

Yagi, R., Fidalski, J., \& Tormena, C. A. (2014). A incorporação de calcário em sistema plantio direto consolidado reduz o estoque de carbono em macroagregados do solo. Cienc. Rural, 44(11), 1962-1965. https://doi.org/ $10.1590 / 0103-8478 \mathrm{cr} 20140339$

Zambrosi, F. C. B., Alleoni, L. R. F., \& Caires, E. F. (2007). Aplicação de gesso agrícola e especiação iônica da solução de um Latossolo sob sistema plantio direto. Cienc. Rural, 37(1), 110-117. https://doi.org/10.159 0/S0103-84782007000100018

Zoca, S. M., \& Penn, C. (2017). An important tool with no instruction manual: A review of gypsum use in agriculture. Adv Agro, 144, 1-44. https://doi.org/10.1016/bs.agron.2017.03.001

\section{Copyrights}

Copyright for this article is retained by the author(s), with first publication rights granted to the journal.

This is an open-access article distributed under the terms and conditions of the Creative Commons Attribution license (http://creativecommons.org/licenses/by/4.0/). 